ROCZNIKI KULTUROZNAWCZE

Tom XII, numer $4-2021$

DOI: http://doi.org/10.18290/rkult21124-2

IRENEUSZ KAMIŃSKI

\title{
SEKTY I ALTERNATYWNE RUCHY RELIGIJNE. STAN WIEDZY - PRÓBA SYSTEMATYZACJI
}

\section{WPROWADZENIE}

W artykule przedstawiono podstawowe informacje na temat sekt (określanych często jako nowe ruchy religijne - dalej: nrr). Najpierw wskazano etymologię terminu, następnie skupiono się na funkcjonujących terminach zastępczych, dalej opisano próby uchwycenia definicji tego fenomenu, przeanalizowano relacje pomiędzy sektą i religią oraz między sektą a Kościołem, oraz zaprezentowano kilka klasyfikacji i typologii sekt. Podkreślono główne trudności towarzyszące badaniom sekt i alternatywnych ruchów religijnych. Na koniec postawiono pytanie o możliwość wyłonienia się nowej dziedziny naukowej sektologii/sektoznawstwa.

\section{ETYMOLOGIA ${ }^{1}$}

Wyraz „sekta” wyprowadza się z dwóch źródeł łacińskich: (1) sequor, sequi - 'iść', 'podążać za', 'postępować za', 'naśladować'; secedo - 'odchodzę',

Mgr IRENEUSz KAMIŃSKI - Uniwersytet Mikołaja Kopernika w Toruniu, Wydział Teologiczny, Katedra Teologii Systematycznej, Pracownia Dokumentacji i Badań Alternatywnych Ruchów Religijnych i Parareligijnych; adres do korespondencji: Wydział Teologiczny UMK, ul. Gagarina 37, 87-100 Torun; e-mail: irrreeek@tlen.pl; ORCID: https://orcid.org/0000-0002-2331-4569.

${ }^{1}$ Za: Ireneusz KAMIŃSKI, „II.1. Terminologia - sekta czy nowy ruch religijny”, w: Ireneusz KAMIŃSKI, Sekty $i$ nowe ruchy religijne $w 365$ pytaniach i odpowiedziach. Praktyczny poradnik na temat sekt, alternatywnych ruchów religijnych i parareligijnych (Warszawa: Vocatio, 2013), 24-27; KAMIŃSKI, „Wprowadzenie do zagadnienia sekt i alternatywnych ruchów religijnych (etymologia; etiologia; teoretyczne opisy: źródła, definicje, klasyfikacje, modele i ich typologie; skala; konsekwencje; profilaktyka, terapia i ruch pomocowy)”, w Sekty i nowe ruchy religijne - wolność czy zniewolenie? Zagadnienia interdyscyplinarne, red. Ireneusz Kamiński i Piotr Chrzczonowicz (Toruń: Kunke Poligrafia, 2012), 13-14. 
'oddalam się' - czyli sekta to sposób postępowania, droga, którą podążają jej adepci zainspirowani i prowadzeni przez charyzmatycznego przywódcę; (2) seco, secare, sectare - 'odcinać', 'obcinać', 'oddzielać', 'ciąć', 'odrąbywać', 'rozdzielać' ${ }^{2}$ - czyli sekta to grupa, która oddzieliła się (poprzez doktrynę lub praktykę) od innej dużej grupy ${ }^{3}$. Ta druga etymologia jest mniej ścisła, choć oba ujęcia trafnie określają zjawisko sekt. Różni autorzy opowiadają się za jedną, drugą lub obiema etymologiami tego słowa, ze względu na to, że najpierw następuje element (1) odcięcia się, a następnie (2) podążania za kimś. Tak więc te dwie koncepcje mogą się wzajemnie dopełniać ${ }^{4}$. W klasycznej grece, jak i w grece Nowego Testamentu, łacińskiemu słowu 'sekta' odpowiada synonim określenie heiresis, który oznacza 'wybór', 'kierunek'.

Jeśli chodzi o sposób powstania, to sekta (1) może być zupełnie nowym tworem, niezależnym od innych grup, organizacji lub (2) może zaistnieć poprzez rozłam większej, głównej wspólnoty.

Tak więc etymologia i budowane na niej definicje tego fenomenu nie zawierają elementów wartościujących. W Europie słowo „sekta” budzi skojarzenia negatywne, choć pejoratywne rozumienie tego terminu pojawiło się dopiero w średniowieczu pod wpływem kontrowersyjnych, ekstremalnych i nagannych zachowań członków sekt. Bardzo długo więc pojęcie „sekta” funkcjonowało jako neutralne.

\section{TERMINY ZASTĘPCZE 5}

Obok terminu „sekta” pojawiają się nowe, równoznaczne i alternatywne, z których największy zasięg ma nominacja „nowy ruchy religijny”. Uchodzi za pojęcie nieobciążone żadnym sądem aksjologicznym (wartościującym) i dlatego jest obiektywne, czy nieobraźliwe ${ }^{6}$. Niektórzy jednak wskazują braki i wady terminu nrr. Twierdzą, że nie wszystkie grupy tak opisywane są

\footnotetext{
${ }^{2}$ Paweł SzuPPE, „Sekty. Informacje i profilaktyka w dużym skrócie”, w Sekty. Społeczne i prawno-polityczne aspekty zjawiska. Zbiór studiów, red. Ireneusz Kamiński i Marek Płodowski (Olsztyn: Abigail, 2009), 341.

${ }^{3}$ Maciej SzosTAK, Sekty destrukcyjne. Studium metodologiczno-kryminalistyczne (Kraków: Zakamycze, 2001), 39.

${ }^{4}$ Marcin PYTLaK, Rozpoznać sektę. Kryteriologia sekt (Lublin: Instytut Zastosowań Techniki, 2002), 14.

${ }^{5}$ Za: KAMIŃSKI, „Wprowadzenie do zagadnienia sekt”, w Sekty i nowe ruchy religijne - wolność czy zniewolenie? 13-16; KAMIŃSKI, „II.1. Terminologia - sekta czy nowy ruch religijny”, 27-32.

${ }^{6}$ Maria LiBiszowsKa-ŻóŁtKowsKA, Nowe ruchy religijne $w$ zwierciadle socjologii (Lublin: Wydawnictwo UMCS, 2001), 48-50.
} 
(1) religijne i (2) nowe 7 , a określeniu nrr brakuje „spójności i konkretności”8. Termin ten uchodzi za zbyt pojemny i definicyjnie nieostry w stosunku do klasycznego określenia „sekta”". Można także zauważyć, że nominacja „nowy ruch religijny" nie do końca jest neutralna, ponieważ zawiera przymiotnik „nowy”, który raczej dowartościowuje opisywane tą nazwą grupy, albowiem nowość jest, w naszym kręgu kulturowym, traktowana jako coś pozytywnego ${ }^{10}$.

Proponuje się, zatem inne terminy zamiast nrr, np.: „,nowe grupy religijne”, „nowe religie”, „ruchy kultowe” „ugrupowania religijnego pogranicza” $(\text { urp })^{11}$ - obok niewątpliwych zalet posiadają one wady, do których można zaliczyć, np. brak konkretności. ${ }^{12}$ Funkcjonują także określenia mniej neutralne, np.: ,grupy psychodestrukcyjne”, „destrukcyjne grupy psychomanipulacyjne” (dgp),${ }^{13}$ „,totalitarne grupy religijne”, ,sekty destrukcyjne”. ${ }^{14}$ Istnieją ponadto określenia takie jak: "ruch parareligijny", "nowy ruch magiczny" (nrm) ${ }^{15}$, "wspólnoty światopoglądowe". ${ }^{16}$ Pojawiają się też nazwy: „grupy psychomanipulacyjne”, ,kontrowersyjne grupy religijne” (kgr), ${ }^{17}$,grupy duchowych nadużyć” (gdn), ${ }^{18}$,antyspołeczne grupy religijne” (agr), ,grupy marginesu

\footnotetext{
${ }^{7}$ Gerardus VAn DER Leeuw, Fenomenologia religii, wyd. 2, thum. Jerzy Prokopiuk (Warszawa: Książka i Wiedza, 1997), 236-237.

${ }^{8}$ Władysław NowaK, Sekty w Polsce (Olsztyn: Kuria Metropolitalna, 1995), 13.

${ }^{9}$ LiBiszowsKa-ŻóŁtKowsKa, Nowe ruchy religijne, 50; Hanna GrZYMAŁA-MoszczYŃSKA, Psychologia religii, wybrane zagadnienia (Kraków: Nomos, 1991), 221.

${ }^{10}$ Robert T. PTASZEK, Filozoficzne aspekty alternatywnej religijności (Lublin: Polskie Towarzystwo Tomasza z Akwinu, 2021), 11.

${ }^{11}$ Zbigniew PASEK, „Ugrupowania religijnego pogranicza”, w Sekty jako wyzwanie spoleczne i religijne. VI Interdyscyplinarne Sympozjum Wydziału Teologii Uniwersytetu Warmińsko-Mazurskiego, red. Władysław Nowak i Sławomir Ropiak (Olsztyn: Wydawnictwo UWM, 2005), 79 (materiały z konferencji naukowej zorganizowanej przez UWM - Wydział Teologii „Sekty jako wyzwanie społeczne i religijne" 14-15.10.2005 r.).

${ }^{12}$ Bogdan FERDEK, Sekty i nowe ruchy religijne (Wrocław: alta 2, 1998), 29-31; Marian RUSECKI, „Dlaczego sekty są niebezpieczne?”, w Problemy współczesnego Kościoła, red. Marian Rusecki (Lublin: Wydawnictwo KUL, 1996), 204-209.

13 Jacek MARUCHIN, „Dlaczego powstają sekty? Próba definicji”, W: Tomasz ALEXIEWICZ i Jacek MARUCHIN, Wiara w pigutce, czyli sekty (Poznań: Inicjatywa Wydawnicza Jerozolima, 2003), 7.

${ }^{14}$ Maciej SzostaK, Sekty destrukcyjne. Studium metodologiczno-kryminalistyczne (Kraków: Zakamycze, 2001), 57-75.

${ }^{15}$ Massimo InTrovigne, Powrót magii (Kraków: WAM, 2005).

${ }^{16}$ Aleksander POSACKI, ,Sekty, nowe ruchy religijne, psychokulty - geneza, definicje, typologia”, w Sekty, sekty..., red. Maria Renkielska (Kielce: Jedność, 1997), 8-9.

${ }^{17}$ Dariusz Kuncewicz, Kontrowersyjne grupy religijne. Psychologiczne aspekty przynależności (Tychy: Maternus Media, 2005).

${ }^{18}$ Ireneusz KAMIŃSKI, „Tabela przymusu i grupy duchowych nadużyć według A. Bidermana (tabela Bidermana) (1961)”, w: KAMIŃSKI, Wspótczesne teorie sekty i psychomanipulacji. Teoretyczne modele opisujace sekty, nowe ruchy religijne i psychomanipulacje $w$ ujęciu wybranych autorów (Toruń: Druk-Tor, 2011), 52-56.
} 
religijnego (gme)", ${ }^{19}$ czy ,alternatywne ruchy religijne” (arr). ${ }^{20}$ Niektórzy zamiast przymiotnika „sekciarski” proponują łagodniejsze ich zdaniem słowo „sektowy”, jeszcze inni mówią o „sektantach". ${ }^{21}$ Istnieje także znane od lat określenie „kulty”, popularne w świecie anglosaskim. Dla sekt o dużym nasileniu szkodliwości stosuje się określenie „sekta destrukcyjna”.

Jednak najpopularniejszym terminem zastępującym „sektę”, pozostaje „,nowy ruch religijny”, jako nominacja niewartościująca i synonimiczna wobec „,sekt”22.

\section{DEFINICJE 23}

Popularna definicja sekty brzmi następująco: jest to izolująca się od społeczeństwa grupa ludzi, posiadająca: przywódców (z silnie wyeksponowaną ich rolą i hierarchią, wśród nich dominujący jest główny lider, często charyzmatyczny założyciel, czasami zwany „guru”), własne wierzenia, wartości oraz zachowania.

Definicje sekty to bardzo delikatna, skomplikowana, a jednocześnie fundamentalna kwestia. Próby jej wypracowania na polu różnych dziedzin naukowych charakteryzują się pewnymi odmiennościami.

${ }^{19}$ Tadeusz ZIELIŃSKI, „Potrzeba dialogu Kościołów z grupami marginesu religijnego w świetle dokumentów środowiska ekumenicznego", w: NowaK i RoPIAK, Sekty jako wyzwanie społeczne i religijne, 35-47.

${ }^{20}$ Robert T. PTASZEK, Nowa Era religii? Ruch New Age i jego doktryna - aspekt filozoficzny (Siedlce: Wydawnictwo Akademii Podlaskiej, 2008), 9-10.

${ }^{21}$ Piotr STAwiŃSKI, „Fenomen sekt w ujęciu historyczno-socjologicznym”, w Sekty. Uwarunkowania i niebezpieczeństwa w III Rzeczypospolitej Polskiej. Materiały z ogólnopolskiej konferencji naukowej zorganizowanej przez Instytut Pedagogiki Społecznej WSP w Częstochowie, 20-21.11.2000, red. Stanisław Pamuła i Andrzej Margasiński (Częstochowa: Wyższa Szkoła Pedagogiczna w Częstochowie, 2001), 21.

${ }^{22}$ Warto jednak zauważyć, iż dotyczy to większości dyscyplin naukowych, jednakże poza np. naukami prawnymi, a szczególnie prawem karnym i kryminologią, które z uwagi na specyficzny cel za przedmiot badań obejmują wyłącznie zjawiska społecznie szkodliwe i towarzyszące im zwykle pojęcia o negatywnym nacechowaniu. Zob.: Marta ROMAŃCZUK-GRĄCKA, Kryminologiczne aspekty sekt destrukcyjnych (Olsztyn: Wydawnictwo UWM, 2008), 33-42.

${ }^{23}$ Za: Joanna KULWICKA-KAMIŃSKA, „Pojęcie sekty - rozważania terminologiczne”, w: KAMIŃSKI i PŁODOwsKi, Sekty. Obrona czy tolerancja?, 25-39; KAMIŃSKI, „Wprowadzenie do zagadnienia sekt i alternatywnych ruchów religijnych”, 23-25; KAMIŃSKI, „II.2. Definicja sekty”, w: KAMIŃSKI, Sekty i nowe ruchy religijne $w 365$ pytaniach i odpowiedziach, 35-41. 


\subsection{TEOLOGIA I RELIGIOZNAWSTWO}

Cechy sekt przedstawiają w kontekście: (1) Kościoła/macierzystej grupy odcięcie się i zerwanie z dotychczasowym wyznaniem religijnym; (2) Biblii/ innych świętych ksiąg (np. Koranu, Wed) - przyjęcie dodatkowych źródeł objawienia („,nowe objawienia”) stojących ponad tymi tradycyjnymi świętymi księgami (np. Księga Mormona w stosunku do Biblii); (3) soteriologicznym redukowanie powszechnej woli zbawienia do własnej grupy; (4) dialogu religijnego - odrzucenie dialogu i jednoczesne propagowanie synkretyzmu; ${ }^{24}$ (5) eschatologicznym - posiadanie silnej orientacji na bliski koniec świata ${ }^{25}$ (zupełnie podobne zdanie reprezentuje Joseph Ratzinger ${ }^{26}$ ). Dla sekt odchrześcijańskich wskazuje się dodatkowo kwestie: (6) historyczne - brak ciągłości od czasów Chrystusa i apostołów - powstali w wyniku działania swojego założyciela (twierdzą zazwyczaj, iż „prawda" była obecna za czasów apostolskich, potem wygasła, a pojawiła się ponownie w chwili powstania peich grupy); (7) trynitarystyczne - brak wiary w Trójcę Świętą i Jezusa jako Boga i Zbawiciela.

Jan Paweł II w dokumencie Niebezpieczeństwo prozelityzmu sekt religijnych, który stanowi Orędzie na Światowy Dzień Migranta z 1990 r., stwierdza, że można wskazać pewne ogólne tendencje wśród sekt, które głoszą zazwyczaj, że:

- zbawienie jest udziałem tylko niewielkiej grupy;

- kierują nią ludzie obdarzeni wybitną osobowością;

- wierzą, iż są związani z Bogiem uprzywilejowaną relacją;

- utrzymują, że tylko oni znają Jego tajemnicę;

- poszukiwanie sacrum w tych grupach jest albo najwyższą wartością, ku której człowiek dąży, choć nigdy jej nie osiąga, albo osadzone jest w świecie magii, gdzie człowiek próbuje sprowadzić je do sfery swego oddziaływania, aby nim manipulować i sobie je podporządkować $(\mathrm{nr} 2)^{27}$.

\footnotetext{
${ }^{24}$ Friederike VALENTIN, „Sekten“, w: Hans GASPER, Joachim MÜLlER i Friederike VALEnTIN, Lexikon der Sekten, Sondergruppen und Waltanschaungen (Freiburg im Breisgau: Herder, 1991), 921-953.

${ }^{25}$ Bogdan FERDEK, „Próba określenia sekty”, Effatha 17, nr 5 (1992): 15-17.

${ }^{26}$ Joseph RAtZIngER i Vittorio MeSsori, Raport o stanie wiary. Z ks. J. Ratzingerem rozmawia Vittorio Messori (Kraków-Warszawa: Michalineum, 1986), 100-101.

${ }^{27}$ JAN PAWEŁ II, „Niebezpieczeństwo prozelityzmu sekt religijnych. Orędzie na Światowy Dzień Migranta 1990 r.”, w Orędzia Ojca Świętego Jana Pawła II, tom 1, red. Jacek Jękot i Piotr Słabek (Kraków: Wydawnictwo św. Stanisława BM, 1998), 383-387; Ireneusz KAMIŃSKI, „Dokumenty kościelne dotyczące sekt i nowych ruchów religijnych. Prezentacja i próba klasyfikacji”, w: NowAK i ROPIAK, Sekty jako wyzwanie spoleczne i religijne, 272-273.
} 


\subsection{SOCJOLOGIA}

Definicje te na pierwszy plan wysuwają problem oderwania się od jakiegoś oficjalnego Kościoła, dużej grupy religijnej, trwania w opozycji wobec pozostałych grup społecznych, izolacji od środowiska zewnętrznego, dalej wskazują niezależność i nonkonformizm, odrębność światopoglądową, ideologiczną i społeczną, dobrowolne uczestnictwo w sekcie z wyboru, a nie z urodzenia, autorytaryzm i fanatyzm członków, silne wewnątrzorganizacyjne zespolenie, autorytarne/totalitarne, czy charyzmatyczne przywództwo (socjotechniki).

\subsection{PSYCHOLOGIA}

Definicje akcentują głównie czynnik manipulacji (psychomanipulacji), zarówno w procesie werbowania do sekty, jak i podczas trwania w sekcie, a także zagrożenie różnych sfer życia człowieka (destrukcja psychiczno-duchowa, społeczna, fizyczna), a więc patologie, które dotknąć mogą przede wszystkim sfery osobowościowej członków sekt.

\subsection{JEZYKOZNAWSTWO}

Definicje koncentrują się na manipulacji w sferze językowej (językomanipulacje głównie w środkach perswazji), co wykorzystywane jest do werbowania adeptów sekty i nauczania członków, a także do budowania propagandowego pozytywnego wizerunku na zewnątrz grupy.

\subsection{PRAWO-POLITOLOGIA}

Definicje te zwracają uwagę na występowanie sekt przeciwko prawom człowieka i swobodom obywatela oraz na godzenie w ludzką godność, jak i porządek w aspekcie społecznym i polityczno-prawnym (sekta jako „totalitarna wyspa otoczona oceanem demokracji”). Raport polskiego Ministerstwa Spraw Wewnętrznych i Administracji z 2000 r. ${ }^{28}$ podaje, że sekta to grupa ludzi:

- posiadająca silnie rozwinięte struktury władzy,

- charakteryzująca się znaczną rozbieżnością deklarowanych celów od celów realizowanych,

- ukrywająca normy, regulujące w sposób istotny życie uczestników grupy,

${ }^{28}$ Wiktor MiKruT i Grzegorz MiKRUT (red.), Raport o niektórych zjawiskach zwiazanych $z$ działalnościa sekt w Polsce (Warszawa: MSWiA, 2000); oraz George A. MATHER, Larry A. NICHOLS i Alvin J. SCHMIDT, Stownik sekt, nowych ruchów religijnych i okultyzmu (Warszawa: Vocatio, 2006), 569-612. 
- naruszająca podstawowe prawa człowieka i zasady współżycia społecznego,

- wpływająca na swoich członków (jednostkę, rodzinę), sympatyków i społeczeństwo w sposób destrukcyjny. ${ }^{29}$

Podkomisja ds. Grup Psychomanipulacyjnych Komisji Rodziny Sejmu dodała, że sekta (grupa psychomanipulacyjna) to zbiór ludzi, który poprzez stosowanie technik psychologicznych i socjologicznych i wykorzystanie fizyczne, psychiczne lub materialne, powoduje uzależnienie osoby od sekty lub jej przywódcy ${ }^{30}$. Natomiast francuski rządowy raport z lutego 2000 r. Międzyministerialnej Misji do Walki z Sektami (MILS) ${ }^{31}$ dodaje, iż sekta posiada strukturę i charakter totalitarny, może, ale nie musi głosić poglądów religijnych, a jej działania godzą w ludzką godność i prawa oraz porządek społeczny ${ }^{32}$.

\subsection{INNE DEFINICJE (NP. PEDAGOGICZNE, ETNOLOGICZNE, HISTORYCZNE)}

Okazuje się, iż nie istnieje jedna, uniwersalna, powszechnie akceptowalna i precyzyjna definicja sekty. Niemożność stworzenia satysfakcjonującej wszystkich badaczy definicji nie oznacza, że należy rezygnować ze stosowania tego pojęcia. ${ }^{33}$ Próba stworzenia definicji sekty nie jest zadaniem łatwym, a niektórzy stwierdzają wręcz, że podanie jej jest niemożliwe. Elmer T. Clark w efekcie studiów nad bogatym materiałem empirycznym doszedł do wniosku, że sekta jest bardziej związana z kwestią ducha, niż formy, organizacji lub wielkości i wobec tego nie jest możliwe dokładne zdefiniowanie tego terminu. ${ }^{34}$

\footnotetext{
${ }^{29}$ KAMIŃSKI, „Wprowadzenie do zagadnienia sekt i alternatywnych ruchów religijnych”, 25.

${ }^{30}$ KAMIŃSKI, Sekty i nowe ruchy religijne w 365 pytaniach i odpowiedziach, 40.

${ }^{31}$ Ireneusz KAMIŃSKI, Raport Komisji ds. Walki z Sektami Republiki Francuskiej (MILS) z 2000 r., w: KAMIŃSKI, Sekty i nowe ruchy religijne $w$ oficjalnych dokumentach. Klasyfikacja, analizy, komentarz i teksty źródlowe (raporty, rezolucje, zalecenia, uchwaty, rozporzadzenia) (Toruń: Druk-Tor, 2011): 86-87.

32 Józef MAJEWSKI, „Beneficjentki kryzysu. Niektóre społeczno-kulturowe aspekty sekt”, w Ochrona szkoły przed sektami i psychomanipulacja, red. Krystyna Kmiecik-Baran i Stefan Kubowicz (Gdańsk: Instytut Promocji Nauczycieli, 2002), 21.

${ }^{33}$ PytLaK, Rozpoznać sektę, 15.

${ }^{34}$ Ewa M., GuZIK, „Prawne aspekty działalności s. religijnych w Polsce”, Państwo i Prawo, nr 3 (2000): 45 .
} 


\section{SEKTA A RELIGIA ${ }^{35}$}

Można by sądzić, iż sekty i nrr powinny być głównie lub wyłącznie analizowane na polu badawczym religioznawstwa, co wiązałoby się z ujęciem sekty jako zjawiska całkowicie religijnego. Okazuje się jednak, że sekta przekracza sferę religijności, ponieważ można obserwować i wyróżnić obok sekt religijnych także sekty o charakterze niereligijnym, na przykład, politycznym, terapeutyczno-edukacyjnym i ekonomicznym, a nawet rozrywkowym, czy humorystycznym. Funkcjonują one jako „religie zastępcze”, „kulty świeckie” czy pseudoreligie, lecz bez wyraźnego nawiązania do religii w tradycyjnym znaczeniu. Trudno jest uchwycić granicę pomiędzy sektą a religią, ${ }^{36}$ lecz nie znaczy to, że tej granicy nie ma, ale na pewno nie jest tak, że pojęcie „sekta” całkowicie zawiera się w pojęciu „religia”. Analiza doktryny i praktyki sekt „raczej zaprzecza religijnemu charakterowi sekt”. ${ }^{37}$ Niektórzy wręcz twierdzą, iż sekty nie proponują żadnej wiary, lecz dają możliwość adeptom doświadczania wewnętrznej wolności, która jednak różni się od wolności opartej na rozumie $i$ indywidualnym sumieniu. ${ }^{38}$

Z kolei większość badaczy zjawiska religii (religioznawcy, religiolodzy) jest zgodnych co do tego, że religia posiada pozytywny wpływ na życie człowieka, na jego psychikę i inne sfery, podczas gdy sekta może wywoływać skutki negatywne. ${ }^{39}$ Każde pozytywne zjawisko - także autentyczna, zdrowa religia - niestety posiada swoją „,ciemną stronę”, czyli pseudoreligię, „,parodię religii”, która jest karykaturą religii, stając się często pożywką dla zaburzeń psychicznych, które może powodować lub rozniecać ${ }^{40}$. Należy podkreślić, że sekty są czymś w rodzaju pseudoreligii, areligii, antyreligii, przeciwieństwa

${ }^{35}$ Za: Ireneusz KAMIŃSKI, „Sektologia (sektoznawstwo) i teoria sekty, czyli perspektywy badań nad sektami i nowymi ruchami religijnymi”, w: KAMIŃSKI, Współczesne teorie sekty i psychomanipulacji, 36; KAMIŃSKI, „II.3. Sekta a inne typy organizacji religijnych”, w: KAMIŃSKI, Sekty i nowe ruchy religijne $w 365$ pytaniach $i$ odpowiedziach, 42-43; KAMIŃSKI, Wprowadzenie do zagadnienia sekt $i$ alternatywnych ruchów religijnych, 39.

${ }^{36}$ Andrzej ZwOLIŃSKI, „Anatomia sekty”, w Sekty. Zamaskowane zniewolenie. Materialy z XXVII Sympozjum Koła Naukowego WSD (Płock 18-20.11.2004), red. Remigiusz Stacherski (Płock: Płocki Instytut Wydawniczy, 2005), 31.

37 PyTLAK, Rozpoznać sektę, 18.

${ }^{38}$ Eugenio FizzotTI, „Satanizm z punktu widzenia psychologii. Sekty i kulty satanistyczne”, L'Osservatore Romano 18, nr 6 (1997): 59-61.

39 Józef URBAN, „Sekty dramatem współczesnej rodziny”, w U progu trzeciego tysiąclecia chrześcijaństwa. Wyklady otwarte zorganizowane w okresie Wielkiego Postu 2001 roku, red. Marcin Worbs (Opole: Wydział Teologiczny Uniwersytetu Opolskiego, 2001), 49.

40 Andrzej ZwoliŃSKI, Anatomia sekty (Kraków: Gotów; 1996; Radom: Polskie Wydawnictwo Encyklopedyczne, 2004), 273-276. 
religii, czy rodzajem złej religii. Używają one maski religijności, aby pod nią funkcjonować i rozwijać się, ponieważ sfera religii w państwach demokratycznych objęta jest szerokim polem wolności sumienia i wyznania. Wolności te, w tym wypadku, używane są przez sekty do ochrony swej patologicznej i destruktywnej działalności (religia jako „maska”).

Doktryna sekciarska posiada cechy, odróżniające ją od religii, czy grup nie-sekciarskich. Są to:

1) redukcjonizm - uproszczona interpretacja nauk wielkich religii (m.in. wypaczona wizja zbawienia, koncepcji Boga;

2) fundamentalizm - zaostrzenie interpretacji doktryny, odwoływanie się do rzekomej pierwotnej gorliwości, a także akcentowanie posiadania czystej nauki i wiary;

3) selekcjonizm - rozbudowanie niektórych wątków powszechnie znanych doktryn; podawanie odpowiedzi jasnych, krótkich i prostych, nawet na trudne i głębokie pytania; także moralność sekt jest jasna, pozbawiona kazuistycznych zawiłości, a dowody nie są oparte na argumentacji, czy kompetencjach naukowych, lecz posiadają charakter oczywisty lub są owocem ekstazy, uzdrowienia, zachwytu, daru, wyjątkowego fenomenu itd.;

4) elekcjonizm (i ekskluzywizm) - wybraństwo sekty i właściwe głoszenie światu prawdziwych doktryn, które ,inni” zdradzili; przekonanie, że tylko sekta głosi prawdę, wyłącznie jej członkowie dostąpili zbawienia i tylko oni zostali „wybrańcami” Boga, zaś pozostali tkwią w „ciemności”; tak więc z elekcjonizmu rodzi się ekskluzywizm, czyli poczucie wyłączności na posiadanie prawdy i „dostępu” do Boga;

5) synkretyzm - stworzenie syntezy kilku doktryn religijnych; czerpanie z różnych źródeł może być wynikiem ewolucji danej doktryny;

6) niejasność i niejednoznaczność - szczególnie występuje to w doktrynach sekt wschodnich;

7) spektakularne wizje przyszłości świata, a szczególnie chodzi o:

- katastroficzną wizję świata (strach przed wojną nuklearną, degradacją środowiska, gwałtownością klęsk żywiołowych, głodem, cierpieniem i nędzą);

- przekonanie o istnieniu innych cywilizacji i ich wpływie na losy Ziemi (mocna wiara w istnienie UFO, udział kosmitów w życiu ziemskim, obserwację Ziemi z kosmosu itd.);

- mit nowej ery, mit wiecznego powrotu, co jest wyrazem tęsknoty za kulturą integralną, cywilizacją harmonii, która jakoby istniała w przeszłości (wiara w zagubione cywilizacje, mit Atlantydy, mit idealnej cywilizacji wedyjskiej w Indiach) - jest to spotęgowane nadzieją na ponowne przyjście 
Chrystusa lub innego wybawcy ludzkości - idea mesjasza odradzającego ludzkość (np. Kościół Zjednoczenia Moona);

- wizja „życia po życiu” - chodzi o przyszłość, której oczekują wyznawcy sekty; jest tu miejsce na gwarancje zbawienia, co przemawia do wyobraźni wyznawców;

- religijne podejście do „nowej nauki” - w przeciwieństwie do skompromitowanej dzisiejszej nauki (np. wynalazku bomby atomowej, licznych klęsk ekologicznych), „nowa nauka” zawiera elementy okultyzmu, magii, spirytyzmu, zjawisk parapsychologicznych, mistycyzmu, naturalnych metod leczenia, czy biodynamicznych zasad uprawy i hodowli (takie podejście reprezentuje np. scjentologia. ${ }^{41}$

\section{SEKTA A KOŚCIÓŁ}

Wielu autorów zestawia cechy sekty i Kościoła, charakteryzując porównawczo oba zjawiska:

- Kościół jest duży, sekta jest niewielka;

- w Kościele człowiek się rodzi, do sekty się wstępuje ${ }^{42}$;

- Kościół to stała i zawodowa hierarchia, sekta to charyzmatyczni przywódcy;

- Kościół posiada praktykę sakramentalną związaną z grzesznością członków, sekta głosi świętość swych członków, indywidualny kontakt z sacrum;

- Kościół uznaje autonomię świata, sekta modeluje świat według swych przekonań;

- sekta jest przeciwna światu, kontestuje społeczny ład i jest elementem anarchizującym, Kościół nie odrzuca świata, nie nawołuje np. do odmowy służby wojskowej, więc jest częściowo akceptowany przez świat;

- sekty posiadają silne więzi wewnątrzgrupowe, członkowie znają się bliżej, Kościół posiada podział na większe parafie, w których wierni trudniej przełamują anonimowość;

- sekta uważa swoją religijną prawdę za wyłączną - jedynozbawczość; Kościół nie jest tak radykalny;

- Kościół to częściowy kompromis ze światem, a sekta odrzuca świat ${ }^{43}$.

\footnotetext{
${ }^{41}$ Ibid., 88-99; ZwOLIŃSKI, Drogami sekt (Kraków: Gotów, 1998), 64-73.

${ }^{42}$ Warto jednakże zauważyć, iż w sektach również rodzą się dzieci, a i do Kościołów wstępują dorosłe osoby, więc to kryterium rozróżniające nie do końca jest ścisłe.

${ }^{43}$ Ernst Troeltsch, „Kościół a sekta”, w Socjologia religii. Wybór tekstów, red. Franciszek Adamski (Kraków: Wydawnictwo Apostolstwa Modlitwy, 1983), 104-109; Janusz SzTUMSKI, „Sekta
} 
Przykłady rozróżnienia między Kościołem a sektą ${ }^{44}$ :

\begin{tabular}{|l|l|l|}
\hline \multicolumn{1}{|c|}{ CECHY } & \multicolumn{1}{|c|}{ KOŚCIÓŁ } & \multicolumn{1}{c|}{ SEKTA } \\
\hline uniwersalność & pożądana & niepożądana \\
\hline członkowie & potencjalnie wszyscy ludzie & tylko religijnie kwalifikowani \\
\hline władza & $\begin{array}{l}\text { hierarchiczna charyzma } \\
\text { urzędu }\end{array}$ & $\begin{array}{l}\text { władza szczególnie } \\
\text { kwalifikowanych }\end{array}$ \\
\hline $\begin{array}{l}\text { stosunek } \\
\text { do świata }\end{array}$ & $\begin{array}{l}\text { akceptujący gotowość } \\
\text { do kompromisów }\end{array}$ & $\begin{array}{l}\text { odrzucający, negujący lub } \\
\text { zwalczający }\end{array}$ \\
\hline $\begin{array}{l}\text { dyscyplina } \\
\text { organizacyjna }\end{array}$ & luźna & rygorystyczna \\
\hline organizacja & biurokratyczna & charyzmatyczna \\
\hline
\end{tabular}

Interesujące jest to, iż niektórzy religioznawcy charakteryzując socjologię religii jako część religioznawstwa stwierdzają, że socjologia religii „wypowiada się na temat procesów sekto- i religiotwórczych", a więc wyraźnie oddzielają i odróżniają sektotwórcze procesy od religiotwórczych - nie zaliczają sekt i nrr do religii ${ }^{45}$.

\section{KLASYFIKACJE I TYPOLOGIE ${ }^{46}$}

Klasyczna klasyfikacja sekt przedstawia się następująco: (1) przebudzeniowe, np. kwakrzy, zielonoświątkowcy; (2) millenarystyczne, np. świadkowie Jehowy, Dzieci Boże; (3) uzdrawiające, np. antoiniści, scjentyści; (4) synkretyczne, np. kaodaizm, antropozofia; (5) gnostyczne, np. teozofia; (6) orientalne (wschodnie), np. Hare Kryszna. ${ }^{47}$

w świetle socjologii”, w Sekty, studium socjologiczno-historyczne (Kielce: Szumacher, 1993), 10; Zygmunt PawŁowICZ, Sekty w Polsce (Gdańsk: Stella Maris, 2000), 9-10; Zbigniew PASEK, Pstrokate piękno. Szkice z historii duchowości chrześcijańskiej (Kraków: Media-Press, 1999), 178; Tadeusz PALECZNY, Sekty w poszukiwaniu utraconego raju (Kraków: Universitas, 1998), 30-31.

${ }^{44}$ Günter KeHRER, Wprowadzenie do socjologii religii, thum. Janusz Piegza (Kraków: Nomos, 1996), 168.

${ }^{45}$ Eugeniusz SAKowicz, Religioznawstwo. Przewodnik tematyczny. Judaizm, islam, hinduizm, buddyzm, sekty, satanizm, New Age, religie ludów pierwotnych (Lublin: Polihymnia, 2005), 28.

${ }^{46}$ Za: KAMIŃSKI, „W Wrowadzenie do zagadnienia sekt i alternatywnych ruchów religijnych”, 25-26.

${ }^{47}$ Jean Vernette, Sekty (Warszawa: Volumen, 1998), 23. 
Jan Paweł II dokonuje prostego podziału sekt na chrześcijańskie, inspirujące się religiami Wschodu, oraz będące echem współczesnych ideologii, przeważnie rewolucyjnych ${ }^{48}$.

Steven Hassan dzieli sekty na: (1) religijne (określona doktryna religijna), (2) polityczne - podstawą działalności jest skrajna (ekstremistyczna), czasami terrorystyczna doktryna polityczna lub religijno-polityczna; (3) edukacyjne, czyli terapeutyczne - prowadzą seminaria, warsztaty, kursy, których uczestnicy dostępują doświadczenia „oświecenia”, „iluminacji”, „otwarcia” itd.; (4) handlowe, czyli ekonomiczne (komercyjne) - nastawione są na osiągnięcie jak największego zysku, żerują na ludzkiej chęci bogacenia się ${ }^{49}$.

Typologia opierająca się na zróżnicowanym stopniu intensyfikacji organizacji, obejmuje:

- audytoria kultowe (kulty audytoryjne) - są niezorganizowane, a uczestnictwo w nich ogranicza się do konsumpcji czasopism, książek i programów $\mathrm{w}$ mediach o tematyce religijnej lub parareligijnej, albo też uczestnictwa w festiwalu lub kursie (większość uczestników jest z kręgu New Age);

- kulty klienteli, które opierają się na relacji terapeuta - klient; koncentracja może nastąpić wokół jakiejś usługi; zdarza się, że któryś z uzdrowicieli, guru czy jasnowidzów pragnie zgromadzić swą klientelę i wówczas powstają:

- ruchy kultowe, czyli typowe sekty - ruchy, które przybierają bardziej skomplikowaną i sformalizowaną strukturę niż poprzednie grupy ${ }^{50}$.

Można dzielić sekty ze względu na ich wewnętrzną budowę, na te o strukturze: piramidy, zakładające pełną hierarchizację; pajęczyny, łączące wiele struktur piramidalnych; gwiazdy, która przypomina koło rowerowe, gdzie guru stanowi centrum osi, zaś adepci to obręcz; kulistej, gdzie każdy z uczestników odgrywa podobną rolę, nie ma hierarchizacji, czy bezpośredniego przywództwa ${ }^{51}$.

${ }^{48}$ JAN PAWEŁ II, „Niebezpieczeństwo prozelityzmu sekt religijnych”, 383-387.

${ }^{49}$ Steven Hassan, Psychomanipulacja w sektach, thum. Ewa Bladowska i Maciej Dynkowski (Łódź: Ravi, 1999), 33, 68-70; HASSAN, Jak uwolnić się od manipulacji psychicznej w sektach? Poradnik dla rodzin i przyjaciót członków destrukcyjnych kultów, tłum. Ewa Bladowska i Maciej Dynkowski (Łódź: Ravi, 2001), 27-33; Grzegorz RowiŃSKI, W niewoli sekt. Podręcznik dla dowódców (Warszawa: Bellona, 2001), 20.

${ }^{50}$ Rodney StARK i William S. BAInBridge, The Future of Religion. Secularization, Revival and Cult Formation (Berkeley: University of California, 1985), 24-30; Piotr J. ŚLIWIŃSKI, Religijna sałatka. Kilka słów o nowych formach religijnych i parareligijnych (Poznań: Księgarnia św. Wojciecha, 1996), 8; ŚLıwiŃSKI, Kraina Wodnika i okolice (Poznań: Księgarnia św. Wojciecha, 1998), 18-19; StARK i BAINBridge, The Future of Religion, 24-30.

${ }^{51}$ Jean-Marie ABGRALl, Sekty. Manipulacja psychologiczna. Terapia ofiar, charyzma guru, techniki uzależniania (Gdańsk: Gdańskie Wydawnictwo Psychologiczne, 2005), 77-81. 
Przyjmując za podstawę podziału sekt ich sposób wyrażania dezaprobaty lub aprobaty wobec świata, można wyróżnić cztery ich typy: (1) dążące do zmiany świata poprzez samodoskonalenie, (2) agresywne wobec świata zewnętrznego, (3) uciekające od świata, (4) aprobujące świat ${ }^{52}$.

Nowatorskim podziałem jest propozycja Massimo Introvigne - dyrektora włoskiego Centrum Ruchów Nowych Religii (CESNUR) w Turynie. Dzieli on sekty ze względu na narastającą degradację i rozkład wierzeń, oddalających się coraz bardziej od chrześcijaństwa, co dzieje się w czterech stadiach. Jego podział można nazwać „typologią czterech NIE”,53 albowiem kolejne „nie” wyznaczają typy sekt, czy nrr:

\section{TYPOLOGIA ,4 NIE”}

CHRYSTUS / KOŚCIÓŁ / BÓG / RELIGIA / SACRUM

1. Nowe ruchy religijne, które odrzucają Kościół, akceptując Chrystusa:

\begin{tabular}{|ll|}
\hline Chrystus: TAK $\quad$ Kościól: NIE \\
\hline
\end{tabular}

Ruchy te mają pochodzenie judeochrześcijańskie i wybiórczo traktują Biblię, akcentując zazwyczaj eschatologię. Mówią dużo na temat powtórnego przyjścia Chrystusa, tysiącletnim królestwie itd. Przykłady: świadkowie Jehowy, mormoni, adwentyści, zielonoświątkowcy i wiele innych grup odprotestanckich.

2. Nowe ruchy religijne odrzucające rolę Chrystusa, a akceptujące Boga:

$$
\text { Bóg: TAK Chrystus: NIE }
$$

Ruchy te są inspirowane religiami wschodu. Uznają istnienie jakiejś istoty absolutnej, natomiast odrzucają Jezusa Chrystusa. Ich rozwój zaczął się w Europie od czasów Rewolucji Francuskiej i trwa do dziś. Można do nich zaliczyć Hare Kryszna, Kościół Zjednoczenia, teozofię, antropozofię, sufizm.

3. Nowe ruchy religijne odrzucające Boga:

\section{Religia: TAK Bóg: NIE}

\footnotetext{
${ }^{52}$ ZwOLIŃSKI, Drogami sekt, 10-15.

${ }^{53}$ Piotr J. ŚLIWIŃSKI, „Typologia nowych ruchów religijnych”, Przegląd Powszechny, nr 1 (1996): 82-87; ŚLIWIŃSKI, Religijna sałatka, 9-11; ŚLIWIŃSKI, Kraina Wodnika i okolice, 11-14; Massimo INTROVIGNE, Storia del New Age 1962-1992 (Piacenza: Cristianità, 1994).
} 
Propagują religijność bez Boga, uwypuklają znaczenie, możliwości rozwoju potencjału człowieka i jego możliwości, jako efekt terapii lub quasi-terapii. Przykłady to: Silva Mind Control, scjentologia, UFO-kulty, a także proreligijna część New Age.

4. Nowe ruchy religijne odrzucające religię:

Sacrum: TAK Religia: NIE

Odrzucając religię, akceptują sacrum, które tu występuje, lecz nie posiada znaczenia religijnego. Sacrum to siła, moc, pojmowana w sposób magiczny. Poprzez działania i obrzędy magiczne grupy te pragną sterować i podporządkowywać te nadnaturalne siły swoim potrzebom. Przykłady to: okultyzm, spirytyzm, masoneria, różokrzyżowcy, sataniści, spirytyści - będą to zatem grupy praktykujące wszystkie formy zorganizowanej magii. Można te nrr inaczej nazwać nowymi ruchami magicznymi (nrm), które stanowią czwartą najbardziej oddaloną od chrześcijaństwa grupę nowych ruchów religijnych (nrr).

\section{TRUDNOŚCI BADAWCZE ${ }^{54}$}

Problematyka sekt jest zagadnieniem trudnym i złożonym, wynikającym co najmniej z trzech przyczyn:

- różnorodności dyscyplin naukowych, które zajmują się tym problemem,

- wielości i różnorodności koncepcji wyjaśniających to zjawisko,

- odmiennych stanowisk światopoglądowych co do oceny sekt jako fenomenu pozytywnego lub negatywnego ${ }^{55}$.

$\mathrm{Na}$ problem naukowego podejścia do sekt ma jednak przemożny wpływ kwestia wcześniejszych rozstrzygnięć światopoglądowych (filozoficznych), które rzutują na badaczy zajmujących się sektami, co pośrednio determinuje i przesądza rezultaty wszelkich wyników badań nad sektami. Rozstrzygnięcie, czy grupa religijna np. stosuje „manipulację psychologiczną” ma w istocie charakter filozoficzny, ponieważ wymaga wprowadzenia kategorii podmiotowego i przedmiotowego (instrumentalnego) traktowania człowieka, co stanowi już wstęp do rozważań etycznych (czyli filozoficznych) $)^{56}$.

\footnotetext{
${ }^{54} \mathrm{Za}$ : Ireneusz KAMIŃSKI, „Badania nad sektami i nowymi ruchami religijnymi - statystyka, literatura i inne źródła wiedzy”, w: KAMIŃSKI, Współczesne teorie sekty i psychomanipulacji, 22.

${ }^{55}$ Sławomir BuKALSKI, Podatność młodzieży na oddziaływania grup kultowych (Szczecin: Wydawnictwo Naukowe Uniwersytetu Szczecińskiego, 2006), 17.

${ }^{56}$ KunCEWICZ, Kontrowersyjne grupy religijne, 6.
} 


\section{PODSUMOWANIE: SEKTOZNAWSTWO (SEKTOLOGIA) KOLEJNĄ DZIEDZINĄ NAUKOWĄ? ${ }^{57}$}

Czy możliwe jest ukonstytuowanie się nowej dziedziny nauki ${ }^{58}$ określanej jako „sektologia” (T. Alexiewicz) ${ }^{59}$, „sektoznawstwo” (I. Kamiński) i „teoria sekty" (I. Kamiński)?

Ta nowa gałąź naukowa ${ }^{60}$ musiałaby osiągnąć dostateczny stopień samodzielności epistemologicznej i metodologicznej (odrębny, nowy przedmiot badań naukowych i nowe, specyficzne metody badawcze). Zajmowałaby się wyłącznie badaniem fenomenu określanego jako „sekty” lub „,nowe ruchy religijne". Duże znaczenie dla dalszych rozważań w tym kierunku będzie miała kwestia metodologii badań nad sektami i nrr ${ }^{61}$.

${ }^{57}$ Ireneusz KAMIŃSKI, „Sektologia (sektoznawstwo) i teoria sekty, czyli perspektywy badań nad sektami i nowymi ruchami religijnymi”, w: KAMIŃSKI, Wspótczesne teorie sekty i psychomanipulacji, 29-40.

${ }^{58}$ „Na naszych niejako oczach rodzą się coraz nowe dyscypliny naukowe. Jest to zrozumiałe, powstają bowiem nowe obszary, cele i metody badań, wywołane potrzebą bardziej szczegółowych i dokładniejszych rezultatów poznawczych lub prostszych ujęć. Specjalizacja nie jest jednak cnotą, lecz złem koniecznym, dlatego badanie specjalistyczne ma wartość o tyle, o ile sprzyja integracji poznania. [...] Zróżnicowanie i specjalizacja przebiega bowiem bardziej spontanicznie niż unifikacja" - Stanisław KAMIŃSKI, Nauka i metoda. Pojęcie nauki i klasyfikacja nauk (Lublin: Towarzystwo Naukowe KUL, 1998), 275; KAMIŃSKI, Pojęcie nauki i klasyfikacja nauk (Lublin: Towarzystwo Naukowe KUL, 1961).

${ }^{59}$ Tomasz AleXIEWICZ, „W jaki sposób działają sekty?”, w: Tomasz ALEXIEWICZ i Jacek MARUCHIN, Wiara w pigutce, czyli sekty (Poznań: Inicjatywa Wydawnicza Jerozolima, 2003), 51.

${ }^{60}$ Oczywiście można sobie wyobrazić jeszcze inne określenia tego typu, np. „kultologia”, „kultoznawstwo” (cultology). Prof. Alexander L. Dvorkin prowadzi katedrę, którą określa się w języku angielskim jako: Departament of Cultology (Katedra Wiedzy o Sektach) - Alexander DvorkIN, "Overview of the Activity of Health-Related Cults in the Countries of the Former USSR", w The Phenomenon of Cults from a Scientific Perspective, red. Piotr T. Nowakowski (Kraków: Rafael, 2007), 323.

${ }^{61}$ Vittorio LANTERNARI, „Religioznawstwo a nowe ruchy religijne. Zagadnienia metodologiczne”, Euhemer - Przegląd Religioznawczy, nr 2 (1980): 23-30; Zdzisław CHLEwiŃsKi, Anna GrZYWA i Adam STANOWSKI, „Metodologiczne aspekty badania przekonań”, Roczniki Filozoficzne 33, nr 4 (1985): 69-94; Tadeusz DOKTÓR, „Metodologiczne problemy badania nowych ruchów religijnych”, Przegląd Religioznawczy, nr 1 (1994): 57-66; Maria LiBISzOwSKA-ŻóŁtKOwSKA, „Metodologiczne problemy badań nowych ruchów religijnych”, Przegląd Religioznawczy, nr 1 (1997): 65-77; Jurij HAŁAJKO i Marta ZIMNIAK, „Badania nad nowymi ruchami religijnymi: RUNWira”, Zagadnienia Naukoznawstwa, nr 3 (1998): 321-345; Marta ZIMNIAK-HAŁAJKO, „Metoda uczestnicząca w badaniu nowych ruchów religijnych”, Zagadnienia Naukoznawstwa, nr 1 (2000): 43-62; Maria LiBISZOwSKAŻóŁTKOWSKA, „Metodologiczne problemy badań nowych ruchów religijnych”, w Nowe ruchy religijne. Wybrane problemy, red. Zbigniew Stachowski (Warszawa-Tyczyn: Wyższa Szkoła SpołecznoGospodarcza, 2000); Maciej SzostaK, „Metodologiczne problemy badań sekt destrukcyjnych”, w: SzostaK, Sekty destrukcyjne. Studium metodologiczno-kryminalistyczne (Kraków: Zakamycze, 2001), 231-430; Marta LIBISZOWSKA-ŻÓŁTKOWSKA, „Metodologia badań nad nowymi ruchami religijnymi”, Nomos, nr 39-40 (2002); Zbigniew PASEK, „Badania nad nrr z perspektywy Pracowni 
Liczni badacze omawianego zagadnienia mówią o: „psychologii sekt”

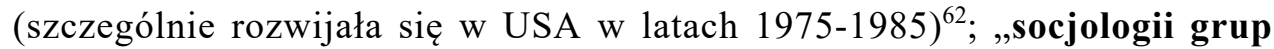
parareligijnych i paranaukowych" ${ }^{\prime 63}$ czy „socjologii sekty”"64; psychologii sekty” ${ }^{\prime 65}$; ,psychiatrii sekty" ${ }^{\prime 66}$; ,etiologii sekty” ${ }^{, 67}$, a niektórzy mówią nawet

Dokumentacji Wyznań Religijnych w Polsce Współczesnej Instytutu Religioznawstwa UJ (komunikat)”, Nomos, nr 39-40 (2002): 145-152; Marta ZiMNIAK-HAŁAJKO, „Obecne kierunki badań nrr”, w: ZiMNIAK-HAŁAJKO, Raj oswojony. Antropologia nowych ruchów religijnych (Gdańsk: Słowo, obraz, terytoria, 2003), 24-25; Szymon BEźNIC, „Etyczne i metodologiczne dylematy badania nowych ruchów religijnych", w Walka, tolerancja, dialog, wspótpraca wobec sekt i nowych ruchów religijnych, red. Andrzej Potocki (Poznań: Fundacja Przeciwdziałania Uzależnieniom „Dominik”, 2005), 97-128.

${ }^{62}$ Walter MARTIN i Gretchen PASSANTINO, „Psychologiczna struktura sekt”, w: MARTIN, Świat religii i sekt (Warszawa: Chrześcijański Instytut Biblijny, 2004), 43.

${ }^{63}$ Krzysztof KoseŁA, „Grupy pogranicza nauki i religii. Wprowadzenie w problematykę socjologiczną", w Ruchy pogranicza religii i nauki jako zjawisko socjopsychologiczne, red. Tadeusz Doktór i Krzysztof Koseła (Warszawa: Uniwersytet Warszawski, 1984), 1:8; Ewa M. GUZIK-MAKARUK, Sekty religijne w Polsce (Warszawa: Kodeks, 2004), 40.

${ }^{64}$ ZwOLIŃSKI, Anatomia sekty, [Kraków] 55, [Radom] 74; ZwOLIŃSKI, „Anatomia sekty”, w Abc o sektach, red. Mariusz GAJEwSKI (Tychy: Maternus; Kraków: Civitas Christiana, 2004), 45; Jan SzMYD, „Sekty religijne”, w Encyklopedia psychologii, red. Włodzimierz Szewczuk (Warszawa: Fundacja Innowacja, 1998), 806; Andrzej WoŁPIUK, Przyczyny i motywy przynależności do sekt i nowych ruchów religijnych (Kraków: Wydawnictwo PAT, 2006), 102; Marcin PYTLAK, „Socjologia sekt”, w: PYTLAK, Rozpoznać sektę. Kryteriologia sekt (Lublin: Instytut Zastosowań Techniki, 2002), 18, 74-107.

Prof. Stephen A. Kent z Uniwersytetu w Albercie prowadzi m.in. oddzielne wykłady określane jako socjologia religii (sociology of religion) oraz ,socjologia grup sektowych” (sociology of sectarian groups) - Stephen A. KENT i Joseph P. SzIMHART, „Exit Counseling and the Decline of Deprogramming”, w: NowAKOWSKI, The Phenomenon of Cults, 367.

${ }^{65}$ HASSAn, Psychomanipulacja w sektach, 9, 116-140; MARTIN i PASSANTINO, „Psychologiczna struktura sekt”, w: MARTIN, Świat religii i sekt (Warszawa: Chrześcijański Instytut Biblijny, 2004), 43; PYTLAK, „Psychologia sekt”, 108-149; PYTLAK, Rozpoznać sektę, 113-158; SZMYD, „Sekty religijne”, w: SzEWCZUK, Encyklopedia psychologii, 806.

Dariusz Kuncewicz prowadził seminarium fakultatywne w roku akademickim 2006/2007 w Szkole Wyższej Psychologii Społecznej w Warszawie pt. „Psychologia sekt” (psychology of cults). Tematyka zajęć obejmowała: (1) psychologię zjawisk związanych z powstawaniem sekt, (2) mechanizmy psychologiczne specyficzne dla uczestnictwa w sekcie, czyli związane z przystępowaniem, uczestnictwem i odchodzeniem z takich grup, (3) cele i sposoby pomocy psychologicznej osobom/rodzinom zgłaszającym trudności na tle przynależności do sekt. Zob. także: Dariusz KUNCEWICZ, „Rewriting Narratives of Traumatic Experiences in a Cult Environment", w: NowAKOwSKI, The Phenomenon of Cults, 61.

Prof. Philip Zimbardo - światowa sława w dziedzinie psychologii społecznej i przewodniczący Zachodniego Towarzystwa Psychologów - na Uniwersytecie Stanforda wygłaszał cykl wykładów pt. „Psychologia kontroli umysłu” (zob. www.zimbardo.com); HASSAN, Jak uwolnić się od manipulacji psychicznej w sektach?, 187.

${ }^{66}$ Józef URBAN, „Sekty dramatem współczesnej rodziny”, w Sekty. Uwarunkowania i niebezpieczeństwa w III Rzeczypospolitej Polskiej, 93; Zwolı́́SKI, Anatomia sekty, [Kraków] 179, [Radom] 277; ZwoLIŃSKI, Sekty... Dlaczego? (Warszawa: Wydawnictwo Sióstr Loretanek, 1998), 139.

${ }^{67}$ Maciej SzostaK, Sekty destrukcyjne. Studium metodologiczno-kryminalistyczne (Kraków: Zakamycze, 2001), 292; WoŁPIUK, Przyczyny i motywy przynależności do sekt (Kraków: Wydawnictwo PAT, 2006), 58. 
o „teorii powstawania sekt" ${ }^{\prime 6}$ czy „teorii syndromu ofiary sekty" ${ }^{\prime 9}$. M. Zimniak-Hałajko własne opisy „w co wierzą i jak żyją członkowie neoreligijnych wspólnot”, czyli antropologiczne badania kultury sekt i nrr, nazywa ,antropologią nowych ruchów religijnych”, co można uznać za próbę budowania „etnologii sekt" ${ }^{\prime 70}$. Mówi się też o ,antropologii sekt" ${ }^{\text {"71 }} \mathrm{i}$,historii sekt" ${ }^{\text {"72 }}$ wyodrębnionej z ogólnej historii religii. Z łatwością można również wyobrazić sobie, na przykład, „geografię sekt”. Istnieją także pewne koncepcje zmierzające do stworzenia teorii

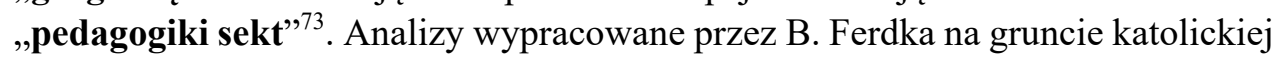
teologii dogmatycznej można z powodzeniem określić jako „teologię sekty”74.

E. Voegelin (zm. 1985) swojej filozofii polityki i historii idei nie traktował w oderwaniu od kwestii religii i gnozy, a jego analizę dziejów idei można z powodzeniem określić jako próbę uprawiania „filozofii sekty”75. W jego ujęciu cała dzisiejsza (nowożytna) kultura i społeczeństwo są stworzone przez gnozę i przez to są sektocentryczne. Również zbliżone poglądy, ostrzegające przed gnozą, wyrażał już wcześniej J. M. Hoene-Wroński (zm. 1853) ${ }^{76}$. „Filozofię sekty” obecnie w Polsce rozwija R. T. Ptaszek ${ }^{77}$.

${ }^{68}$ Aleksander POSACKI, „Sekty, nowe ruchy religijne, psychokulty - geneza, definicja, typologia”, w Sekty, sekty..., red. Maria Renkielska (Kielce: Jedność, 1997), 8.

${ }^{69}$ MARTIN i PASSANTINO, ,Psychologiczna struktura sekt”, 43.

${ }^{70}$ ZimniaK-HAŁAJKo, „Obecne kierunki badań nrr”, 24. Sporo miejsca w tej pracy autorka poświęca metodologii badań (s. 35-74).

${ }^{71}$ SZMYD, ,Sekty religijne”, 806.

${ }^{72}$ Ibid., 806.

${ }^{73}$ Mariusz GAJEwSKI, „Możliwości i ograniczenia profilaktyki społecznej w obszarze kontrowersyjnych grup kultowych i sekt”, w KAMIŃSKI i PŁODOwsKI, Sekty. Społeczne i prawno-polityczne aspekty zjawiska; Piotr T. NOWAKOWSKI, „Uzasadnienie ujęcia problemu sekt na gruncie pedagogiki resocjalizacyjnej”, w Sekty jak problem wspótczesności, red. Piotr T. Nowakowski (Mysłowice: Górnośląska Wyższa Szkoła Pedagogiczna, 2008), 183, 189.

${ }^{74}$ Katolicka „teologia sekty” zajmowałaby się badaniem sekt i nrr metodą teologiczną, czyli z punktu widzenia objawienia chrześcijańskiego, korzystając z wyników badań nauk religioznawczych, które rozpatrywałaby w świetle własnego objawienia. Zob. Bogdan FERDEK, Sekty i nowe ruchy religijne jako problem teologiczny (Wrocław: Papieski Fakultet Teologiczny, 1997); FERDEK, Sekty i nowe ruchy religijne.

${ }^{75}$ Zob. Eric Voegelin, Lud Boży (Kraków: Znak, 1994); Voegelin, Nowa nauka polityki (Warszawa: Aletheia, 1992), s. 115 i rozdz. 4: „Gnoza - istota nowożytności”; Monika UmiŃSKA (tłum.), ,Słowo od thumacza”, w: Voegelin, Lud Boży; Paweł ŚPIEWAK (thum.), Wstęp, w: Voegelin, Nowa nauka polityki.

${ }^{76}$ Polski filozof Józef Maria Hoene-Wroński za istotę nowożytnych ruchów społecznych uznawał „gnozimachiczność”. Próby obalenia ładu polityczno-prawnego - za pomocą rewolucji - destabilizacja hierarchicznej struktury społecznej, czyli ostatecznie destrukcja tradycyjnego systemu wartości (systemu aksjonormatywnego), stanowić miały oś nowej rzeczywistości, w której więzi wspólnotowe zostaną zastąpione przez więzi kolektywne, budowane na wzór starożytnych idei gnostyckich - zob. Zbigniew KUDEROWICZ, „Gnozimachia. Ostrzeżenie Hoene-Wrońskiego”, w Gnoza polityczna, red. Jan Skoczyński (Kraków: Księgarnia Akademicka, 1998), 13; Marcin ZARZECKI, „Konwertyci nowych ruchów religijnych. Ujęcie z perspektywy współczesnych koncepcji socjologicznych”, w NowAK i ROPIAK, Sekty jako wyzwanie społeczne i religijne, 253.

${ }^{77}$ PtASZEK, Nowa Era religii?; PTASzeK, Filozoficzne aspekty alternatywnej religijności. 
Nie można nie zauważyć istnienia już od starożytności herezjologii czy herezjografii, czyli nauki o herezjach. Choć uważa się, że nauka ta jest bardzo „kostyczna”, to jednak budzi ona i dziś gorące emocje i odgrywa istotną rolę w życiu dzisiejszych społeczności religijnych (np. muzułmańskich ${ }^{78}$.

Rozwój badań nad sektami i nrr przynieść może co najmniej cztery modelowe scenariusze w zakresie systematyki dziedzin, dyscyplin i gałęzi nauki:

a) ukonstytuowanie się niezależnej, samodzielnej dyscypliny naukowej, tzn. sektoznawstwa/sektologii, badającej wyłącznie sekty i nrr oraz posługującej się metodami zapożyczonymi z innych nauk humanistycznych - byłaby to nauka niejako równoległa do religioznawstwa (czy szerzej religiologii), korzystająca w szczególny sposób z jego metodologii oraz posiadająca zapewne swoje subdyscypliny (analogicznie: historia sekty, socjologia sekty, psychologia sekty itd., ale także filozofia sekty, teologia sekty);

b) wytworzenie się kolejnej subdyscypliny w ramach religioznawstwa (religiologii), która będzie wykazywała odrębność od pozostałych gałęzi tej nauki (nauk religioznawczych) - byłaby to dyscyplina interdyscyplinarna równoległa do pozostałych szczegółowych gałęzi religioznawstwa (religiologii), wyróżniona ze względu na autonomiczny przedmiot badawczy, którym byłyby sekty i nrr; również i ona posługiwała się metodami badawczymi nauk humanistycznych (ten model wydaje się najbardziej realny);

c) pozostanie badań nad sektami i nrr w sferze dotychczasowego umiejscowienia $\mathrm{w}$ ramach obecnych dyscyplin i specjalności naukowych, co ma zapewne miejsce obecnie (np. socjologia religii);

d) możliwe narodziny sektoznawstwa/sektologii jako nauki o zbliżonym statusie do tego jaki posiada, np. islamistyka (nauka zajmująca się badaniem dziejów i doktryny islamu), ${ }^{79}$ buddologia, czy indologia, będących częścią orientalistyki.

BIBLIOGRAFIA

ABgrall, Jean-Marie. Sekty. Manipulacja psychologiczna. Terapia ofiar, charyzma guru, techniki uzależniania. Tłum. Wiesława Dzieża. Gdańsk: Gdańskie Wydawnictwo Psychologiczne, 2005.

AleXIEWICZ, Tomasz. „W jaki sposób działają sekty?”. W: Tomasz AlEXIEwICZ i Jacek MARUCHIN, Wiara w pigutce, czyli sekty, 41-58. Poznań: Inicjatywa Wydawnicza Jerozolima, 2003.

\footnotetext{
${ }^{78}$ Zbigniew LANDOwSKi, Islam. Nurt, odtamy, sekty (Warszawa: Książka i Wiedza, 2008), 8.

${ }^{79}$ Janusz DANECKI, Kultura islamu. Stownik (Warszawa: Wydawnictwa Szkolne i Pedagogiczne, 1997), 98, 154.
} 
Bauman, Zygmunt. Ciało i przemoc w obliczu ponowoczesności. Toruń: Wydawnictwo UMK, 1995.

BEŹNIC, Szymon. „Etyczne i metodologiczne dylematy badania nowych ruchów religijnych”. W Walka, tolerancja, dialog, wspótpraca wobec sekt i nowych ruchów religijnych, red. Andrzej Potocki, 97-128. Poznań: Fundacja Przeciwdziałania Uzależnieniom „Dominik”, 2005.

BUKALSKI, Sławomir. Podatność młodzieży na oddziaływania grup kultowych. Szczecin: Wydawnictwo Naukowe Uniwersytetu Szczecińskiego, 2006.

Chlewiśski, Zdzisław, Anna GrZYwa i Adam StANOwSKI. „Metodologiczne aspekty badania przekonań”. Roczniki Filozoficzne 33, nr 4 (1985): 69-94.

Danecki, J. Kultura islamu. Stownik (Warszawa:

DokTóR, Tadeusz. „Metodologiczne problemy badania nowych ruchów religijnych”. Przegląd Religioznawczy, nr 1 (1994).

Dvorkin, Alexander. "Overview of the Activity of Health-Related Cults in the Countries of the Former USSR". W: NOWAKOWSKI, The Phenomenon of Cults, 311-323.

FERDEK, Bogdan. „Próba określenia sekty”. Effatha 17, nr 5 (1992): 15-17.

FERDEK, Bogdan. Sekty i nowe ruchy religijne jako problem teologiczny. Wrocław: Papieski Fakultet Teologiczny, 1997.

FERDEK, Bogdan. Sekty i nowe ruchy religijne. Wrocław: alta 2, 1998.

FizzotTi, Eugenio. „Satanizm z punktu widzenia psychologii. Sekty i kulty satanistyczne”. L'Osservatore Romano 18, nr 6 (1997): 59-61.

GAJEWSKI, Mariusz. „Możliwości i ograniczenia profilaktyki społecznej w obszarze kontrowersyjnych grup kultowych i sekt”. W Sekty. Społeczne i prawno-polityczne aspekty zjawiska, red. Ireneusz Kamiński i Marek Płodowski, 86-92. Olsztyn: Abigail, 2009.

GrzymaŁa-MoszczyŃSKA, Hanna. Psychologia religii. Wybrane zagadnienia. Kraków: Nomos, 1991.

GuziK, Ewa M. „Prawne aspekty działalności sekt religijnych w Polsce”. Państwo i Prawo, nr 3 (2000).

GuZiK-MAKARuK, Ewa M. Sekty religijne w Polsce. Warszawa: Kodeks, 2004.

HAŁAJKO, Jurij, i Marta ZIMNIAK. „Badania nad nowymi ruchami religijnymi: RUNWira”. Zagadnienia Naukoznawstwa 34, nr 3 (1998): 321-345.

Hassan, Steven. Jak uwolnić się od manipulacji psychicznej w sekcie? Poradnik dla rodzin i przyjaciót członków destrukcyjnych kultów. Tłum. Ewa Bladowska i Maciej Dynkowski. Łódź: Ravi, 2001.

Hassan, Steven. Psychomanipulacja w sektach. Tłum. Ewa Bladowska i Maciej Dynkowski. Łódź: Ravi, 1999.

Introvigne, Massimo. Powrót magii. Kraków: WAM, 2005.

InTROVIGne, Massimo. Storia del New Age 1962-1992. Piacenza: Cristianità, 1994.

JAN PAWEŁ II. „Niebezpieczeństwo prozelityzmu sekt religijnych. Orędzie na Światowy Dzień Migranta 1990 r.”. W Orędzia Ojca Świętego Jana Pawła II, tom 1, red. Jacek Jękot i Piotr Słabek. Kraków: Wydawnictwo św. Stanisława BM, 1998.

KAMIŃSKI, Ireneusz. „Badania nad sektami i nowymi ruchami religijnymi - statystyka, literatura i inne źródła wiedzy”. W: KAMIŃSKI, Wspótczesne teorie sekty i psychomanipulacji, 13-22.

KAMIŃSKI, Ireneusz. „Dokumenty kościelne dotyczące sekt i nowych ruchów religijnych. Prezentacja i próba klasyfikacji”. W: NOWAK I ROPIAK, Sekty jako wyzwanie społeczne i religijne, 260-294. 
KAMIŃSKI, Ireneusz. „II.1. Terminologia - sekta czy nowy ruch religijny”. W: KAMIŃSKI, Sekty i nowe ruchy religijne $w 365$ pytaniach $i$ odpowiedziach, 24-34.

KAMIŃSKI, Ireneusz. „II.2. Definicja sekty”. W: KAMIŃSKI, Sekty i nowe ruchy religijne w 365 pytaniach i odpowiedziach, 35-41.

KAMIŃSKI, Ireneusz. „II.3. Sekta a inne typy organizacji religijnych”. W: KAMIŃSKI, Sekty $i$ nowe ruchy religijne $w 365$ pytaniach $i$ odpowiedziach, $42-49$.

KAMIŃSKI, Ireneusz. Raport Komisji ds. Walki z Sektami Republiki Francuskiej (MILS) z 2000 r. W: KAMIŃSKI, Sekty i nowe ruchy religijne, 86-87.

KAMIŃSKI, Ireneusz. „Sektologia (sektoznawstwo) i teoria sekty, czyli perspektywy badań nad sektami i nowymi ruchami religijnymi”. W: KAMIŃSKI, Wspótczesne teorie sekty i psychomanipulacji, 24-40.

KAMIŃSKI, Ireneusz. Sekty i nowe ruchy religijne $w 365$ pytaniach i odpowiedziach. Praktyczny poradnik na temat sekt, alternatywnych ruchów religijnych i parareligijnych. Warszawa: Vocatio, 2013.

KAMIŃSKI, Ireneusz. Sekty i nowe ruchy religijne w oficjalnych dokumentach. Klasyfikacja, analizy, komentarz i teksty źródłowe (raporty, rezolucje, zalecenia, uchwały, rozporządzenia). Toruń: Druk-Tor, 2011.

KAMIŃSKI, Ireneusz. „Tabela przymusu i grupy duchowych nadużyć według A. Bidermana (tabela Bidermana) (1961)". W: KAMIŃSKI, Współczesne teorie sekty i psychomanipulacji, 52-56.

KAMIŃSKI, Ireneusz. „Wprowadzenie do zagadnienia sekt i alternatywnych ruchów religijnych (etymologia; etiologia; teoretyczne opisy: źródła, definicje, klasyfikacje, modele i ich typologie; skala; konsekwencje; profilaktyka, terapia i ruch pomocowy)". W Sekty i nowe ruchy religijne - wolność czy zniewolenie? Zagadnienia interdyscyplinarne, red. Ireneusz Kamiński i Piotr Chrzczonowicz, 421-422. Toruń: Kunke Poligrafia, 2012.

KAMIŃsKI, Ireneusz. Wspótczesne teorie sekty i psychomanipulacji. Teoretyczne modele opisujące sekty, nowe ruchy religijne i psychomanipulacje w ujęciu wybranych autorów. Torun: DrukTor, 2011.

KAMIŃSKI, Stanisław. Nauka i metoda. Pojęcie nauki i klasyfikacja nauk. Lublin: Towarzystwo Naukowe KUL, 1998.

KAMIŃSKI, Stanisław. Pojęcie nauki i klasyfikacja nauk. Lublin: Towarzystwo Naukowe KUL, 1961.

KeHRER, Günter. Wprowadzenie do socjologii religii. Tłum. Janusz Piegza. Kraków: Nomos, 1996.

Kent, Stephen A., i Joseph P. SzIMHART. „Exit Counseling and the Decline of Deprogramming”. W: NowAKOwSKI, The Phenomenon of Cults, 327-367.

KoseŁA, Krzysztof. „Grupy pogranicza nauki i religii. Wprowadzenie w problematykę socjologiczną”. W Ruchy pogranicza religii i nauki jako zjawisko socjopsychologiczne, red. Tadeusz Doktór i Krzysztof Koseła. T. 1. Warszawa: Uniwersytet Warszawski, 1984.

Kuderowicz, Zbigniew. „Gnozimachia. Ostrzeżenie Hoene-Wrońskiego”. W Gnoza polityczna, red. Jan Skoczyński, 6-17. Kraków: Księgarnia Akademicka, 1998.

KULWICKA-KAMIŃSKA, Joanna. „Pojęcie sekty - rozważania terminologiczne.” W Sekty. Obrona czy tolerancja? Zagadnienia społeczno-prawne, red. Ireneusz Kamiński and Marek Płodowski, 25-39. Toruń-Olsztyn: Abigail, 2008.

Kuncewicz, Dariusz. Kontrowersyjne grupy religijne. Psychologiczne aspekty przynależności. Tychy: Maternus Media, 2005. 
KunCEwICZ, Dariusz. "Rewriting Narratives of Traumatic Experiences in a Cult Environment". W: NowAKOwSKI, The Phenomenon of Cults, 55-61.

LANDOWSKI, Zbigniew. Islam. Nurt, odtamy, sekty. Warszawa: Książka i Wiedza, 2008.

LANTERNARI, Vittorio. „Religioznawstwo a nowe ruchy religijne. Zagadnienia metodologiczne”. Euhemer - Przegląd Religioznawczy, nr 2 (1980).

LiBISZOWSKA-ŻÓŁTKOWSKA, Maria. „Metodologia badań nad nowymi ruchami religijnymi”. Nomos, nr 39-40 (2002): 11-28.

LIBISZOWSKA-ŻÓŁTKOWSKA, Maria. „Metodologiczne problemy badań nowych ruchów religijnych”. Przegląd Religioznawczy, nr 1 (1997): 65-77.

LiBISZOWSKA-ŻóŁTKOwSKA, Maria. „Metodologiczne problemy badań nowych ruchów religijnych”. W Nowe ruchy religijne. Wybrane problemy, red. Zbigniew Stachowski, 71-85. Warszawa: Polskie Towarzystwo Religioznawcze; Tyczyn: Wyższa Szkoła Społeczno-Gospodarcza, 2000.

LiBiszowsKA-ŻóŁTKOWSKA, Maria. Nowe ruchy religijne $w$ zwierciadle socjologii. Lublin: Wydawnictwo UMCS, 2001.

MAJEWSKI, Józef. „Beneficjentki kryzysu. Niektóre społeczno-kulturowe aspekty sekt”. W Ochrona szkoty przed sektami i psychomanipulacja, red. Krystyna Kmiecik-Baran i Stefan Kubowicz, 18-22. Gdańsk: Instytut Promocji Nauczycieli, 2002.

MARIAŃSKI, Janusz. „Pluralizm religijny w nowoczesnym społeczeństwie”. W: NowAK i RoPIAK, Sekty jako wyzwanie społeczne i religijne, 48-64.

MARTIN, Walter, i Gretchen Passantino. „Psychologiczna struktura sekt”. W: Walter MARTIN, Świat religii i sekt, 43-57. Warszawa: Chrześcijański Instytut Biblijny, 2004.

MARUChIN, Jacek. „Dlaczego powstają sekty? Próba definicji”. W: Tomasz ALEXIEwICZ i Jacek MARUCHIN, Wiara w pigutce, czyli sekty, 5-26. Poznań: Inicjatywa Wydawnicza Jerozolima, 2003.

MATHER, George A., Larry A. NICOLS i Alvin J. SCHMIDT. Stownik sekt, nowych ruchów religijnych i okultyzmu. Warszawa: Vocatio, 2006.

MiKRUT, Wiktor, i Grzegorz MiKRUT (red.). Raport o niektórych zjawiskach zwiazanych $z$ działalnościq sekt $w$ Polsce. Warszawa: MSWiA, 2000.

MudRAK, Elżbieta. Fenomen sekt. Diagnoza stanu wiedzy studentów z regionu warmińskomazurskiego na temat sekt $i$ stosowanych przez nie technik manipulacji. Kraków: Impuls, 2007.

Nowakowski, Piotr T. (red.). The Phenomenon of Cults from a Scientific Perspective. Kraków: Rafael, 2007.

NowAK, Władysław, i Sławomir ROPIAK, ed. Sekty jako wyzwanie społeczne i religijne. VI Interdyscyplinarne Sympozjum Wydziału Teologii Uniwersytetu Warmińsko-Mazurskiego. Olsztyn: Wydawnictwo UWM, 2005.

NowAK, Władysław. Sekty w Polsce. Olsztyn: Kuria Metropolitalna, 1995.

NowAKOwSKI, Piotr T. „Uzasadnienie ujęcia problemu sekt na gruncie pedagogiki resocjalizacyjnej”. W Sekty jak problem współczesności, red. Piotr T. Nowakowski, 183-192. Mysłowice: Górnośląska Wyższa Szkoła Pedagogiczna, 2008.

PALECZNY, Tadeusz. Sekty w poszukiwaniu utraconego raju. Kraków: Universitas, 1998.

PASEK, Zbigniew. „Badania nad nrr z perspektywy Pracowni Dokumentacji Wyznań Religijnych w Polsce Współczesnej Instytutu Religioznawstwa UJ (komunikat)". Nomos, nr 39-40 (2002): 145-152. 
PASEK, Zbigniew. Pstrokate piękno. Szkice z historii duchowości chrześcijańskiej. Kraków: MediaPress, 1999.

PASEK, Zbigniew. „Ugrupowania religijnego pogranicza”. W: NOWAK i ROPIAK, Sekty jako wyzwanie spoteczne i religijne, 79-88.

PawŁowicz, Zygmunt. Sekty w Polsce. Gdańsk: Stella Maris, 2000.

POSACKI, Aleksander. „Sekty, nowe ruchy religijne, psychokultury - geneza, definicja, typologia”. W Sekty, sekty..., red. Maria Renkielska, 7-31. Kielce: Jedność, 1997.

POSACKI, Aleksander. „Sekty, nowe ruchy religijne, psychokulty - geneza, definicje, typologia”. W: Stanisław PyszKA, Wiesław DzIEŻa i Aleksander PosACKI, Katolik wobec sekt. Kraków: WAM, 1997.

PTASZEK, Robert T. Filozoficzne aspekty alternatywnej religijności. Lublin: Polskie Towarzystwo Tomasza z Akwinu, 2021.

PTASZEK, Robert T. Nowa Era religii? Ruch New Age i jego doktryna - aspekt filozoficzny. Siedlce: Wydawnictwo Akademii Podlaskiej, 2008.

PytlaK, Marcin. „Psychologia sekt”. W: Marcin PYTLAK, Rozpoznać sektę. Kryteriologia sekt, 108-149. Lublin: Instytut Zastosowań Techniki, 2002.

PyTLAK, Marcin. Rozpoznać sektę. Kryteriologia sekt. Lublin: Instytut Zastosowań Techniki, 2002.

PyTLAK, Marcin. Rozpoznać sektę. Radom: Polwen, 2005.

RATZINGER, Joseph, i Vittorio MESSORI. Raport o stanie wiary. Z ks. J. Ratzingerem rozmawia Vittorio Messori. Kraków-Warszawa: Michalineum, 1986.

ROMAŃCZUK-GRĄCKA, Marta. Kryminologiczne aspekty sekt destrukcyjnych. Olsztyn: Wydawnictwo UWM, 2008.

RowIŃSKI, Grzegorz. W niewoli sekt. Podręcznik dla dowódców. Warszawa: Bellona, 2001.

RUSECKI, Marian. „Dlaczego sekty są niebezpieczne?, W Problemy współczesnego Kościoła, red. Marian Rusecki, 203-223. Lublin: Wydawnictwo KUL, 1996.

Sakowicz, Eugeniusz. Religioznawstwo. Przewodnik tematyczny: judaizm, islam, hinduizm, buddyzm, sekty, satanizm, New Age, religie ludów pierwotnych. Lublin: Polihymnia, 2005.

StARK, Rodney, i William S. BAInBridge. The Future of Religion. Secularization, Revival and Cult Formation. Berkeley: University of California, 1985.

STAwIŃSKI, Piotr. „Fenomen sekt w ujęciu historyczno-socjologicznym”. W Sekty. Uwarunkowania i niebezpieczeństwa w III RP. Materiały z ogólnopolskiej konferencji naukowej zorganizowanej przez Instytut Pedagogiki Społecznej WSP w Częstochowie (20-21.11.2000), red. Stanisław Pamuła i Andrzej Margasiński, 17-24. Częstochowa: Wyższa Szkoła Pedagogiczna w Częstochowie, 2001.

SzMYD, Jan. „Sekty religijne”. W Encyklopedia psychologii, red. Włodzimierz Szewczuk, 806. Warszawa: Fundacja Innowacja, 1998.

SzostaK, Maciej. „Metodologiczne problemy badań sekt destrukcyjnych”. W: Maciej SzostAK, Sekty destrukcyjne. Studium metodologiczno-kryminalistyczne, 231-430. Kraków: Zakamycze, 2001.

SzOSTAK, Maciej. Sekty destrukcyjne. Studium metodologiczno-kryminalistyczne. Kraków: Zakamycze, 2001.

SzTUMSKI, Janusz. „Sekta w świetle socjologii”. W: Janusz SzTUMSKI, Sekty, studium socjologicznohistoryczne, 9-18. Kielce: Szumacher, 1993. 
SzuPPE, Paweł. „Sekty. Informacje i profilaktyka w dużym skrócie”. W Sekty. Społeczne i prawnopolityczne aspekty zjawiska. Zbiór studiów, red. Ireneusz Kamiński i Marek Płodowski, 341-352. Olsztyn: Abigail, 2009.

ŚLIWIŃSKI, Piotr J. Kraina Wodnika i okolice. Poznań: Księgarnia św. Wojciecha, 1998.

ŚLIWIŃSKI, Piotr J. Religijna sałatka. Kilka słów o nowych formach religijnych i parareligijnych. Poznań: Księgarnia św. Wojciecha, 1996.

ŚLIWIŃSKI, Piotr J. „Typologia nowych ruchów religijnych”. Przegląd Powszechny, nr 1 (1996): 82-87.

ŚPIEWAK, Paweł (tłum). Wstęp. W: Eric VoEgELIn, Nowa nauka polityki. Warszawa: Aletheia, 1992.

Troeltsch, Ernst. „Kościół a sekta”. W Socjologia religii. Wybór tekstów, red. Franciszek Adamski, 104-109. Kraków: Wydawnictwo Apostolstwa Modlitwy, 1983.

UMiŃSKA, Monika (tłum.). „Słowo od tłumacza”. W: Eric VoEGELIN, Lud Boży, 5-19. Kraków: Znak, 1994.

URBAN, Józef. „Sekty dramatem współczesnej rodziny”. W Sekty. Uwarunkowania i niebezpieczeństwa w III Rzeczypospolitej Polskiej. Materiały z ogólnopolskiej konferencji naukowej zorganizowanej przez Instytut Pedagogiki i Socjologii WSP w Częstochowie (20-21.11.2000), red. Stanisław Pamuła i Andrzej Margasiński, 89-101. Częstochowa: Wyższa Szkoła Pedagogiczna w Częstochowie, 2001.

URBAN, Józef. „Sekty dramatem współczesnej rodziny”. W U progu trzeciego tysiaclecia chrześcijaństwa. Wykłady otwarte zorganizowane w okresie Wielkiego Postu 2001 r., red. Marcin Worbs, 48-61. Opole: Wydział Teologiczny Uniwersytetu Opolskiego, 2001.

VALEntIN, Friederike. „Sekten”. W: Hans GASPER, Joachim MÜLLER i Friederike VALENTIN, Lexikon der Sekten, Sondergruppen und Waltanschauungen, 921-953. Freiburg im Breisgau: Herder, 1991.

VAN DER LeEuw, Gerardus. Fenomenologia religii. Wyd. 2. Tłum. Jerzy Prokopiuk. Warszawa: Książka i Wiedza, 1997.

VERnETTE, Jean. Sekty. Warszawa: Volumen, 1998.

Voegelin, Eric. Lud Boży. Kraków: Znak, 1994.

Voegelin, Eric. Nowa nuka polityki. Warszawa: Aletheia, 1992.

WoŁPIUK, Andrzej. Przyczyny i motywy przynależności do sekt i nowych ruchów religijnych. Kraków: Wydawnictwo PAT, 2006.

ZARZECKI, Marcin. „Konwertyci nowych ruchów religijnych. Ujęcie z perspektywy współczesnych koncepcji socjologicznych". W: NOWAK i ROPIAK, Sekty jako wyzwanie spoleczne i religijne, 253-259.

ZIELIŃSKI, Tadeusz. „Potrzeba dialogu Kościołów z grupami marginesu religijnego w świetle dokumentów środowiska ekumenicznego". W: NowaK i RoPIAK, Sekty jako wyzwanie spoleczne i religijne, 35-37.

ZIMNIAK-HAŁAJKO, Marta. „Metoda uczestnicząca w badaniu nowych ruchów religijnych”. Zagadnienia Naukoznawstwa, nr 1 (2000): 43-62.

ZimniaK-HaŁAJKo, Marta. „Obecne kierunki badań nrr”. W: Marta ZimniaK-HaŁAJKo, Raj oswojony. Antropologia nowych ruchów religijnych. Gdańsk: Słowo, obraz, terytoria, 2003.

ZwoliŃSKI, Andrzej. Anatomia sekty. Kraków: Gotów, 1996. Radom: Polskie Wydawnictwo Encyklopedyczne, 2004. 
ZwOLIŃSKI, Andrzej. „Anatomia sekty”. W Abc o sektach, red. Mariusz Gajewski, 37-60. Tychy: Maternus; Kraków: Civitas Christiana, 2004.

ZwOLIŃSKI, Andrzej. „Anatomia sekty”. W Sekty. Zamaskowane zniewolenie. Materiały z XXVII Sympozjum Koła Naukowego WSD (Płock, 18-20.11.2004), red. Remigiusz Stacherski, 31. Płock: Płocki Instytut Wydawniczy, 2005.

ZwoliŃSKI, Andrzej. Drogami sekt. Kraków: Gotów, 1998.

Zwolı́́sKI, Andrzej. Sekty... Dlaczego?, Warszawa: Wydawnictwo Sióstr Loretanek, 1998.

\title{
SEKTY I ALTERNATYWNE RUCHY RELIGIJNE. STAN WIEDZY - PRÓBA SYSTEMATYZACJI
}

\author{
Streszczenie
}

Tekst zawiera podstawowe informacje na temat sekt (nowych ruchów religijnych). Została podana etymologia tego terminu, następnie autor skupia się na terminach zastępczych, po czym opisuje próby uchwycenia definicji tego fenomenu. Analizuje relacje pomiędzy sektą i religią oraz między sektą a Kościołem, oraz prezentuje kilka klasyfikacji sekt.

Podkreślone zostały główne trudności towarzyszące badaniom sekt i alternatywnych ruchów religijnych. Na koniec autor stawia pytanie o możliwość wyłonienia się nowej dziedziny naukowej sektologii/sektoznawstwa.

Słowa kluczowe: sekty; nowe ruchy religijne; alternatywne ruchy religijne; kontrowersyjne grupy religijne; grupy duchowych nadużyć; totalitarne grupy religijne; psychomanipulacja; sektologia/sektoznawstwo.

\section{SECTS AND ALTERNATIVE RELIGIOUS MOVEMENTS STATE OF KNOWLEDGE: AN ATTEMPT AT SYSTEMATIZATION}

\section{S u m m a ry}

The text provides some basic information about sects (new religious movements). It presents the etymology of this term, then focuses on substitute terms. Also further attempts to grasp the definition of this phenomenon are described, the relations between sects and religion and between sects and Church are analyzed, and several classifications of sects are presented. The author highlights the main difficulties accompanying research in sects and alternative religious movements. Finally, the question follows if it is likely that a new scientific field of sectology/sect studies can emerge.

Keywords: sects; new religious movements; alternative religious movements; controversial religious groups; groups of spiritual abuse; totalitarian religious groups; psychomanipulation (mind control); sectology/sect studies. 